\title{
Tropomyosin Alpha-3 Chain Isoform 3
}

National Cancer Institute

\section{Source}

National Cancer Institute. Tropomyosin Alpha-3 Chain Isoform 3. NCI Thesaurus. Code C129384.

Tropomyosin alpha-3 chain isoform 3 (247 aa, $92 \mathrm{kDa}$ ) is encoded by the TC22 allele of the human TPM3 gene. This protein may play a role in tumorigenesis. 